\title{
Status Of Child Labour In Hotels Of Hetauda Sub-Metropolitian City
}

Tika Sapkota

Faculty, Hetauda School of Management and Sciences

\begin{abstract}
The problem of child labour, as faced by the developing economics today, has indeed taken on serious dimensions. The exploitative socio-economic structures resulting in the marginalization of the poor have left them with no option but compel them to adopt child labour as a survival strategy. In the study, efforts are made to understand the societal facts about child labour and the root causes of the problem in the context of the socio-economic dynamics prevailing in the country. Child labour is a serious and wide spread problem in Nepal. Hotel, teashop and restaurant work are the most visible and hazardous forms of child labour, which is mostly common in the urban areas of Nepal. Moreover, they are among the most neglected, abused and exploited segments of the population. The study gathered information on hotel, child laborers socio-economic condition, their working condition, root cause of being laborers and problems faced by them. The child laborers come from almost all parts of the country and they are from different castes and ethnic groups. The majority of children are of age group with the average age being 14.5 years. Most of child laborers have their poor condition, step mother scenario, and illiterate family background. The children were found marginally illiterate. The household poverty is the leading cause of being child laborer in general. However, other factors like social injustice, unequal access to resources, large family size, death of earning family members, illiteracy, etc. contribute to enter into labour market from early age. The communicable diseases were prone in child laborers.
\end{abstract}

Keywords; Child Labor, Parent Occupation, Ethnicity, Literacy, Age Group 


\section{Introduction}

The study is accorded to examine the hidden facts and realities of the condition of child laborers, nature and extent of the child labour in the study area, to analyze the root causes of the problem, socio-economic characteristics and investigate health related conditions and environment accordion their working place and situation. The survey of more than three thousand households by Central Bureau of Statistics (CBS) revealed that the proportion of children not attending school is 41 percent in rural areas and 21 percent in urban areas. From the poor households, almost half of the children do not go to school (CBS, 1994). Children working individually are generally found in "informal sectors" most in the urban and market town. These sectors are not registered and not covered by laws protecting children. The important informal sectors employing child labour are carpet weaving, construction, hotels, restaurants and teashops, soap factory, plastic, brick and tiles factories, vehicle workshops and domestic sectors. Self employing children in urban areas do numerous works such as polishing, newspaper selling, rag picking and in street begging. Bonded child labour is said to be common in the Kamaiya system in far-west of Terai district of Nepal (Sharma and Thakurathi, 1998). Stagnant rural sector and deepening poverty in the rural areas have been working as push factors for child labour phenomena. In the context of child labour, different international laws have set varying age limits for the definition. However, the Minimum Age Convention (ILO, 1973) has defined children as those who are below the general limit of 15 years of in special circumstances 14 years.

According to Children's Act (First Amendment), 1997 and Labour Act (First Smendment), 1997 of Nepal, group of people under the age of 16 years are known as children. According to this law, a child under the age of 14 years shall not be employed in any word as a labour and engaged as a labourer against his will. But the children of the age between 14-16 years can work only when they get facilities like less working hour, 6hours per day not more than 36 hours per week. In this way if they work 3 hours continuously they must get rest for a half an hour.

According to the nationally representative sample survey conducted by the Central Department of population Studies of Tribhuvan University, (1996) there are 2-6 million children between the ages of the age of 5-14 years who are economically active. This constitutes 23.1 percent of the total estimated population of the country. Besides, children, particularly girls, help out in domestic chores and their contribution to the household is taken for granted though they may work full time and be denied education. Poverty is both the cause and consequence of child labour. Extreme poverty and landless in the rural areas are fueling child labour not only in urban areas (CWIN, 1989; INSEC, 1996).

The obvious causes of poverty include structural inequality in access to assets, education and health service and the absence of social security systems in many developing countries (Marcus and Caroline, 1996).In most developed countries, child labour issues have only recently come into the spotlight of practical and economic discussions. The problem of child labour has become an emerging issue in Nepal. There is a gradual increase in social awareness among different segments of society on the 
issue and has helped to empower the movement for the right of working children. The growing marginalization among the rural population, rural migration and urbanization, the growth of industries has also contributed to an increase in the magnitude of child labour exploitation. The migration of children to urban areas has been increasing tremendously these days and this had led to the increase of child labour in the urban areas. Children are engaged in various occupation such as manufacture of carpet, garments, confectionaries, crick kilns, stone quarries, constructions of roads and buildings as well as working in domestic service in towns away from their homes in hotel and restaurants as they are weak and uncomplaining and a cheap source of labour (Pradhan, 1995).

Children are the source of inspiration and hope for society. Every society wishes to bring up its children in an atmosphere of love and care in peace and harmony. However, millions of children are forced to live and work in critical circumstances. Children living in least developed countries face more serious problems with Gerard to their survival development and protection. As part of the least developed world, Nepal has been caught in the painful socio-economic and political turmoil for many years. On the one hand, the national economic growth is decreasing whereas on the other hand, the budget allocated for development, including in essential social areas of educational, health and rural drinking water has been shifted to security. The situation directly or indirectly affects children in their social, physical, mental and emotional development (CWIN, 2002).

There are several factors, which are fuelling urbanization such as unequal land distribution, increasing landlessness as more and more rural poor leave for the cities in search of better livelihoods. Over the past two decades, migration from rural to urban areas has increased more than three folds (Sattur, 1993). In Nepal more than 40 percent of the total population of children aged below 14 years and 60 percent out of the total children are economically active supporting their poor families (UNICEF, 1997).

It is unremarkable and therefore invisible. Its roots lie in the poverty of rural Nepalese in the genera, ignorance of the value of education and of child rights in the access of feudal system that many ways still operates and in certain religious and cultural practices which persist into modern times, despite their prohibition by successive Nepali Constitutions and legislation to protect and promote the rights of children (CWIN, 1993).

Nowadays there is a general consensus among national and international communities that children should be protected from all forms of social and economic exploitation and discrimination, whereby they can enjoy their child hood and have opportunities to mental, spiritual, physical and cognitive development. Therefore, children should not be deprived of basic facilities, which are necessary for their survival, protection and development (CDPS, 1997). Rural to urban migration can be considered a primary factor in the rising number of working children in child pottering, stone mining, brick kilns, carpet industry, construction industries, rag-picking, domestic work, hotels, restaurants, and so on. One of the major fields of employment preferred by children is work in hotels. These children are commonly known as Kanchha (boy) and Kanchhi (girl) rather than by 
their own names and identity. In most cases these children are lowly paid and work long hours from dawn to dusk by demand of their employers.

\section{Literature Review}

The concern of child labour issues has been increasing for the last 15 years in the international sphere. In Nepal child work and child labour is becoming increasingly critical to the livelihood strategies of families and communities. As a result, the quality of life for these children and their chances of more prosperous future are diminishing. But the concept of child labour is recent.

Child labour is not a problem of an individual or a family but it has been the problem of the society. Child labour may be regarded broadly as any work of children under condition that interferes with the opportunities for physical development, education and recreation which children require. It is the working of the children at unfit ages for unreasonable hours or under unhealthy conditions (Patternson, 1973).

The constitution of kingdom of Nepal (1990) prohibits employment of minors in factories, mines and any other hazardous work or forced labour (Article, 20). The Children's Act, 1992 states, children below the age of 14 years shall not be employed in work as a labourer. The Labour Act, 1992 states no child under 14 years of age shall be employed in any established (Section 5). The institute of labour services, the Philippines (1994) refers to child labour as the Participation of children (below 15 years of age) in economically gainful activities, whether they are directly remunerated or paid as part of the family unit. It includes working in family enterprises (in agriculture, services or industry), debt bondage, employment and self-employment. Doing household chores for one's own household or family of mendicancy is not considered child labour (ILS, 1994).

Child labour exploitation is an alarming problem in Nepal. This is caused by the existing exploitative socio-economic and cultural structure and political reality of the country. The magnitude of the problem is very high and more transparent in south Asia. Exploitation of child labour in this part of the world is so inhuman and intolerable. No sector of labour is completely free of child labour exploitation (CWIN, 1998).

When children become less important as economic actors they began to have a new role in society. As they were banned from workforce, they also receive responsibility. Although children in most of the times and place have worded and taken an active part in society as a whole, they are now limited in public policies to playing in the family and working for no pay at school. If they are involved in economic activities, they are largely invisible and paradoxical, because children are unable to find employment in the formal work force so they may be forced to word under worse condition in the informal section (Ennew, et.al., 1995) affecting his or her physical, mental health and education adversely. According to the ILO, most children work but all the works by children can't be considered "child labour". Child labour is something different than when young people are being exploited of over worked or deprived of their right to health or education or 
just childhood. The UN (1990) also defines "child labour" in a similar fashion. In some instances, "child worker/labour" is defined as a person in the age group of 5-14 employed for hier or rewarded on a full time basis and includes a self employed child and child assisting his/her parents in their occupations for two or more hours a day. Hence it is clear that irrespective of economic returns any work situation where there is a violation of the child's rights is child labour situation.

In most of the countries, working children are especially visible on urban economic activities such as underground mines, ambulatory vending, washing cars, polishing shoes, on the agricultural land in the villages, in plantations, factories, children working at junkyards, rag pickers, etc. Children are found almost everywhere under varying forms and terms of employment (ILO, 1986).Children's activities of domestic nature referred to activities like care of siblings, kitchen chores, collection of firewood and fodder, cattle grazing, farm works and other for which they are not directly paid, but they worked to assist their parents. For analytical purposes, collection of firewood and fodder, cattle grazing, farm work, and others belonged to household economic activities, whereas care for siblings and kitchen works belonged to non-economic activities. A sizeable number of children were involved in both economic and non-economic activities.

Altogether 59 types of children's economic activities outside the home as paid activities were recorded. These were grouped under six main types of activities. They were: Agricultural Workers: agricultural labour, livestock keeping, poultry farming, cattle grazing and ploughing, managers and workers in garden and nursery; General Technical Workers; Sales Workers: workers in wholesale or retail shops, mobile traders, newspaper sellers and related workers; Service Workers: cook and waiter in hotels and restaurants and relate works, and watchman; Production Workers: workers in rice mills, knitting and carpet weaving, butchers, factory workers, tailoring, hosiery workers, plumbers, jewelry workers, carving and painting and related works; and Construction, Transportation, and Communication Workers: carpentry, transportation workers, construction labour and related workers.

Two major activities of children prevailed: work and current school attendance status. The total numbers of children are divided into working and non-working irrespective of school attendance. Subsequently, non working children are grouped into two. Current school attendance is the sum of the number of children involved in economic and non-economic activities. Many families of the development world are often in dire need of the income support that their children can provide. On the other hand, children in the industrialized countries are often working for pocket money. Poverty which is itself the product of underdevelopment is the major factor. But poverty is not the only cause culturally derived attitudes and values help to sustain child labour (UNICEF,1997).

\section{Level and Pattern of Child Labour in Nepal}

About 2.6 million children in Nepal regularly work which is 41.7 percent of the total children aged 5-14 years. The proportion of working rural children $(43.4 \%)$ is just double 
the corresponding figure for urban children $(23.0 \%)$. The higher word participation rate of children is found in mountain zone (52.2\%) and it is lowest in the Terai (36.6\%). Western Development Region shows the lowest work participation rate whereas Midwest Region $(50.4 \%)$ and Western Region (48.7\%) show the highest rates. The economic participation of rural children $(28.4 \%)$ is higher than that of urban children $(8.5 \%)$. Among ecological zones, the economic participation is higher in Mountain (38\%) and lowest in Terai (21.2\%). The Midwestern region has highest economic participation rate of children (33.4\%) and the Western region has the lowest rate (20.4).The economic participation rate of children without school attendance is estimated to be $10.8 \%$ of which $7.6 \%$ are male and $14.3 \%$ are female. This rate increases with the increase in ages of children of age group 5-9 (5.9\%) to age group $10-14$ (15.7\%). The participation of rural children (11.6\%) is about 5 times more than the urban children (2.3\%). In urban areas, they are equal but in rural areas the participation of girls $(15.4 \%)$ is just double to that of boys (81.1\%) (Suwal,1997).

About 4.5 percent children aged 5-14 are involved in paid activities of which 4.3 percent are males and 4.6 percent are females. About 22.2 percent of the total children aged 5-14 participate in unpaid economic activities, 23.5 percent are males and 20.8 percent are females. In this case also male and female children have similar participation rates irrespective of the background characteristics.

According to the data of Nepal Labour force Survey, 2008 there are 34 percent of total children are child labour. Among them 30 percent are male and 38 percent are female.

\section{UN on the Right of Child}

UN declaration about after 30 years of the Rights of the Child UN adopted the Convention on the Right of child on 20 November 1989, which is ratified by Nepal on the $14^{\text {th }}$ September 1990. The provisions mentioned in CRC are legally bounded for Nepal since it has become state party of the convention. The UN convention on the Right of the children states that:

1. Every child has the inherent right to life, and states shall ensure to the maximum child survival and development.

2. States shall ensure that each child enjoys full rights without discrimination or distinctions of any kind.

3. States shall protect children from physical or mental harm and neglect, including sexual abuse or exploitation.

4. The child is entitled the highest attainable standard of health.

5. Children shall have time to rest and play.

UN has adopted optional protocol to the Convention on the Rights of the Child on the involvement of children in armed conflicts on 25 May 2000 and the sale of children, child prostitution and child pornography also adopted. World Summit for children (1990) was held at the UN Headquarters in New York in 1990. The World, summit for children adopted a declaration on the survival, protection and development of children. Nepal 
ratified the declaration and resolved to work of the special protection of working children and of the abolition of the labour.

\section{Nepal Legislation on Child Labour}

Many laws regarding labour have been formulated in Nepal. Most leading are the Constitution of the Kingdom of Nepal, 1990. Article 11 of the constitution of the Kingdom of Nepal (1990) not only guarantees equality to all citizens and equal protection of the law to all persons, but it also requires that state make special provisions for the protection and advancement of children. Similarly, the law prohibits the trafficking of human beings including children, slaves, serfs and forced laborers. If restricts sale, trafficking and abduction of children.

The Labour Act, 1992

- $\quad$ Prohibits the employment of children under the age of 14.

- $\quad$ Essentially prohibits night and early morning shifts for minor (from 6 p.m to 6 a.m), except under prescribed conditions.

- $\quad$ Provides for initial chech up and medical treatment of employees.

The Children's Act, 1992

- $\quad$ This act institutes legal provisions in order to protect the rights and interest of children, and also allows for their physical, mental and intellectual development.

- $\quad$ Prohibits the employment of children under the age of 14.

- $\quad$ Prohibits the employment of minors, aged 14 to 16 for more than six hours per day and more than 36 hour per week.

- $\quad$ Prohibits the employment of children in work that is likely to be harmful to health or hazardous to life.

In interim constitution of Nepal 2063 has also involved the child right as a basic right of children. Government has also prepared ten years national work plan (2005-2015), for focusing the child right. In the historical peace commitment, 20063 has involved that prohibits the children under the age 18 are not allowed to join in any armed force.

SAARC Initiatives on Child Labour

Colombo Resolution on Children, 1992

As a member of SAARC Nepal has signed the Colombo Resolution. The Colombo Resolution calls for access to and enrollment in primary education for at least 80 percent of boys and 75 percent of girls and completion of primary education by at least 50 percent of boys as well as girls by the year 1995, and progressive and accelerated elimination of child labour.

Third SAARC Ministerial Meeting in Rawalpindi, 1996

The SAARC meeting on children held in Pakistan in1996 adopted a declaration expressing commitment to abolish child labour in forced on hazardous work by 2000 and child labour in general by 2000 . 
The Ninth SAARC Summit in Male, 1997

The SAARC Summit held in Maldives in 1997 declared the years 2000-2010 "The SAARC Decade of the Right of the Child".

Tenth SAARC Summit in Colombo, 1998

The Tenth SAARC Summit of the Heads of States in Colombo, July 1998, proposed a Draft Convention on preventing and combating trafficking in women and children for prostitutions.

\section{Research Methodology}

Being non technical, the paper is basically descriptive and exploratory in nature and based on primary and secondary data. All primary data are derived from field survey with the help of structural questionnaire which is the main component of the study. The secondary data are obtained from books, journals, research reports, magazines, newspapers and other sources. The research design has been adopted to describe and explore the socio- economic situation of hotel, child labours in Hetauda sub-metropolitan of Makawanpur district major problems associated with them. The data are generated by using non-probability sampling technique. Out of the total child laborers employed in hotels of Hetauda sub-metropolitan the 300 child workers have been selected purposively. The study was conducted in the ward no 1, 2, 3, 4, 5 and 10 in Hetauda.

\section{Presentation and Analysis of Data}

Altogether 300 children, those who are migrant (246) and non-migrant (54) from Hetauda sub-metropolitan were interviewed. The analysis included has been divided into family characteristics and personal characteristics of the child laborer. The family characteristics analysis includes the parent's literacy, parent's occupation, family size, parental status and personal characteristics include the caste/ethnicity, age and sex composition, educational status of children and interest to study in the future.

\section{Family Characteristics}

Parent's Literacy of Child Laborers

If either father only or mother only or both are literate then parent's literacy is categorized as literate in this study. Out of total respondents, 38 percent of the child laborers reported that their parents are literate and 62 percent stated illiterate (table 3). Among the male children 37.8 percent reported that their parents are literate and 62.2 percent said illiterate. The literacy rate of parents of child laborers is low because of poverty and lack of awareness. 
Table 1

Distribution of Respondents by Parent's Literacy Status

\begin{tabular}{lcccccc}
\hline \multirow{2}{*}{ Description } & \multicolumn{2}{c}{ Male } & \multicolumn{2}{c}{ Female } & \multicolumn{2}{c}{ Total } \\
& No. & Percent & No. & Percent & No. & Percent \\
\hline Literate & 84 & 37.8 & 30 & 38.4 & 114 & 38.0 \\
Illiterate & 138 & 62.2 & 48 & 61.6 & 186 & 62.0 \\
\hline Total & 222 & $\mathbf{1 0 0 . 0}$ & $\mathbf{7 8}$ & $\mathbf{1 0 0 . 0}$ & $\mathbf{3 0 0}$ & $\mathbf{1 0 0 . 0}$ \\
\hline
\end{tabular}

Source: Field Survey

Parent's Occupation of Child Laborers

In total 60 percent parents of children depend on agriculture and 40 percent of their parents depend on non-agricultural works, such as domestic work, rickshaw driver, manual labour in construction of house, and mining. Among the male child labour 43.3 percent reported that their parents are involved in non-agricultural activities. Among the female children, 69.2 percent reported that their parents depend on agricultural works. Table 4 shows that the higher proportions of female children's parents depend on agricultural works.

Table 2

Parents Occupation of Child Laborers

\begin{tabular}{lcccccc}
\hline \multirow{2}{*}{ Occupation } & \multicolumn{2}{c}{ Male } & \multicolumn{2}{c}{ Female } & \multicolumn{2}{c}{ Total } \\
& No. & Percent & No. & Percent & No. & Percent \\
\hline Agriculture & 126 & 56.7 & 54 & 69.2 & 30 & 60.0 \\
Non-agriculture & 96 & 43.3 & 24 & 30.8 & 20 & 40.0 \\
\hline Total & 222 & $\mathbf{1 0 0 . 0}$ & $\mathbf{7 8}$ & $\mathbf{1 0 0 . 0}$ & $\mathbf{5 0}$ & $\mathbf{1 0 0 . 0}$ \\
\hline
\end{tabular}

Source: Field Survey

Family Size

Table 3 shows that majority of child laborers belong to the families having 7 to 9 members $(60.0 \%)$ which is followed by less than 6 members $(30.0 \%)$. Ten percent child laborers have family size of more than 10 members. It shows that average family size of the child laborers is very large. Among male respondents, 62.2 percent children belong to the families having 7 to 9 members, which is followed by less than 6 members $(29.7 \%)$. So, this result indicates that most of the child laborers are from large families. The large families can't afford sufficient food and other basic needs. Hence, children are compelled to leave their place of origin for their survival or family economy support. 
Table 3

Family Size of Children Laborers

\begin{tabular}{lcccccc}
\hline \multirow{2}{*}{ Family Size } & \multicolumn{2}{c}{ Male } & \multicolumn{2}{c}{ Female } & \multicolumn{2}{c}{ Total } \\
& No. & Percent & No. & Percent & No. & Percent \\
\hline $2-6$ & 66 & 29.7 & 24 & 30.7 & 90 & 30.0 \\
$7-9$ & 138 & 62.2 & 42 & 53.8 & 180 & 60.0 \\
$10-14$ & 18 & 8.1 & 12 & 15.4 & 30 & 10.0 \\
\hline Total & $\mathbf{2 2 2}$ & $\mathbf{1 0 0 . 0}$ & $\mathbf{7 8}$ & $\mathbf{1 0 0 . 0}$ & $\mathbf{3 0 0}$ & $\mathbf{1 0 0 . 0}$ \\
\hline \multicolumn{1}{c}{ Average } & \multicolumn{2}{c}{7.1} & \multicolumn{3}{c}{9.5} & \multicolumn{3}{c}{7.2} \\
\hline
\end{tabular}

\section{Source: Field Survey}

\section{Parental Status}

Table 4 shows that 36 percent respondents have step mothers and no one has step fathers in their families. 62 percent respondents have their own parents and 2 percent respondents don't have their father and mother and even they don't have step fathers and mothers. They have been living with their elder brother. Among the male child laborers, $40.5 \%$ have their step mother. Presents of step mother or death of both parents creates domestic violence in family, which is one of the reasons for driving children out of their home.

Table 4

Step Father/Mother of Child Laborers

\begin{tabular}{lcccccc}
\hline $\begin{array}{l}\text { Step father/ } \\
\text { mother }\end{array}$ & Male & \multicolumn{3}{c}{ Female } & \multicolumn{3}{c}{ Total } \\
\hline Step mother & 90 & 40.5 & 18 & 23.1 & 108 & 36 \\
Own parents & 126 & 56.8 & 60 & 76.9 & 186 & 62 \\
NO parents & 6 & 2.7 & 0 & 0 & 6 & 2 \\
\hline Total & $\mathbf{2 2 2}$ & $\mathbf{1 0 0 . 0}$ & $\mathbf{7 8}$ & $\mathbf{1 0 0 . 0}$ & $\mathbf{3 0 0}$ & $\mathbf{1 0 0 . 0}$ \\
\hline
\end{tabular}

Source: Field Survey

\section{Personal Characteristics}

Distribution of Child Laborers by Caste/Ethnicity

Table 5 shows that the highest proportion of child laborer is Tamang (51.4\%) among males and Tamang (61.5\%) among females. In the same way the proportion of Chepang male child laborers is 27 percent which is in the second position. The second position among females is also chepang ( $15.4 \%)$. The least proportion of child laborers is from Kami and Danuwar caste (4\%). We know that most of the child laborers are from Tamang and Chepang community. In Makawanpur district high numbers of people are from Tamang community, but they have poor socio economic condition, which impact appear on child. 
Table 5

Distribution of Respondent Child Laborers by Caste/Ethnicity

\begin{tabular}{lcccccc}
\hline \multirow{2}{*}{ Caste/Ethnicity } & \multicolumn{2}{c}{ Male } & \multicolumn{2}{c}{ Female } & \multicolumn{2}{c}{ Total } \\
& No. & Percent & No. & Percent & No. & Percent \\
\hline Tamang & 114 & 51.4 & 48 & 61.5 & 162 & 54 \\
Chepang & 60 & 27 & 12 & 15.4 & 72 & 24 \\
Kshetri & 24 & 10.8 & 12 & 15.4 & 36 & 12 \\
Bramhan & 18 & 8.1 & - & - & 18 & 6 \\
Kami/Danuwar & 6 & 2.7 & 6 & 7.7 & 12 & 4 \\
\hline Total & $\mathbf{2 2 2}$ & $\mathbf{1 0 0 . 0}$ & $\mathbf{7 8}$ & $\mathbf{1 0 0 . 0}$ & $\mathbf{3 0 0}$ & $\mathbf{1 0 0 . 0}$ \\
\hline
\end{tabular}

Source: Field Survey

Distribution by Age and Sex

Children are the source of inspiration and hope for society. From the child development perspective, age under 18 is very important period of child in terms of socialization, economic underdevelopment, formation of self-identity as physical, mental and cognitive development. Table 6 presents information of hotel, teashop and restaurant child laborers under the different age group by sex.

Table 6

Distribution of Respondent Child Laborers by Age and Sex

\begin{tabular}{lcccccc}
\hline \multicolumn{1}{c}{$\begin{array}{c}\text { Age } \\
\text { (in years) }\end{array}$} & \multicolumn{2}{c}{ Male } & \multicolumn{2}{c}{ Female } & \multicolumn{2}{c}{ Total } \\
\hline $9-12$ & 36 & 16.2 & 6 & 7.7 & 42 & 14 \\
$13-16$ & 162 & 72.9 & 60 & 76.9 & 222 & 74 \\
17 Over & 24 & 10.9 & 12 & 15.4 & 42 & 12 \\
\hline Total & $\mathbf{2 2 2}$ & $\mathbf{1 0 0 . 0}$ & $\mathbf{7 8}$ & $\mathbf{1 0 0 . 0}$ & $\mathbf{3 0 0}$ & $\mathbf{1 0 0 . 0}$ \\
\hline
\end{tabular}

Source: Field Survey

Table 6 shows that age of child laborers ranges from 9 to 18 years. The highest percent of hotel, restaurant and teashop child laborers are in the age group 13-16 years that is $(74 \%)$, among them $72.9 \%$ among males and 76.9 percent among females. Age under 18 year is very important period of child in terms socialization, physical mental and cognitive development.

\section{Educational Status of Children}

The education is the most important instrument by which we can develop personality and tackle down the problems in proper way and can achieve success in life. Education is an important ornament of human beings, so without it a man cannot be a full-fledged person. So, this study has tried to find the educational status of respondent child laborers. 
Table 7

Educational Status of Hotel Child Laborers

\begin{tabular}{lcccccc}
\hline \multirow{2}{*}{ Education } & \multicolumn{2}{c}{ Male } & \multicolumn{2}{c}{ Female } & & \\
& No. & Percent & No. & Percent & Total No. & Percent \\
\hline Illiterate & 30 & 13.6 & 24 & 30.8 & 54 & 18 \\
Literate & 192 & 86.4 & 54 & 69.2 & 246 & 82 \\
Total & 222 & 100.0 & 78 & 100.0 & 300 & 100.0 \\
Primary (1-5) & 102 & 46 & 42 & 53.8 & 144 & 48 \\
Lower Secondary(6-8) & 54 & 24.3 & 12 & 15.4 & 66 & 22 \\
Class 9-12 & 36 & 16.1 & - & - & $36 \mathrm{~s}$ & 12 \\
\hline
\end{tabular}

Source: Field Survey

Table 7 clearly shows that majority of the respondent child laborers (82\%) are literate with 48 percent having attended primary level education, 22 percent having lower secondary level and among 12 percent 1 is still reading in class 9 and remaining 5 are still reading in class 12 in different college in Hetauda. On the other, 18 percent child laborers are illiterate, 13.6 percent among percent among males and 30.8 among females and they are totally deprived from educational right.

Interest to Study in the Future

In this study, it is found that most of the child laborers want to go to school to make their future better. Though they know the importance of education, due to various reasons they are compelled to dropout from schooling. Table 8 shows whether respondent child laborers are interested towards education or not in the future.

Table 8

Distribution of Respondent Child Laborers by Their Interest to Study inFuture

\begin{tabular}{lcccccc}
\hline \multirow{2}{*}{ Interest to study in future } & \multicolumn{2}{c}{ Male } & \multicolumn{2}{c}{ Female } & \multicolumn{2}{c}{ Total } \\
& No. & Percent & No. & Percent & No. & Percent \\
\hline Yes & 132 & 59.4 & 42 & 53.8 & 174 & 58 \\
No & 90 & 40.6 & 42 & 46.2 & 126 & 42 \\
\hline Total & 222 & 100.0 & 78 & 100.0 & 300 & 100.0 \\
\hline
\end{tabular}

Source: Field Survey

Table 8 shows that significant proportion of child laborers (58\%) were interested to study in the future if someone provides them help. Attitude towards future education is considerably higher among males (59.4\%) than females (53.8\%). However, 42 percent child laborers reported that they are not interested to study in the future. Causes of unwillingness for future education are presented in table 9 . 
Table 9

Distribution of Respondent Child Laborers by Causes of Unwillingness to Study in the Future

\begin{tabular}{lcccccc}
\hline \multicolumn{1}{c}{ Causes } & \multicolumn{2}{c}{ Male } & \multicolumn{2}{c}{ Female } & \multicolumn{2}{c}{ Total } \\
& No. & Percent & No. & Percent & No. & Percent \\
\hline Over age & 42 & 40 & 30 & 83.3 & 66 & 52.4 \\
Dis like to study & 30 & 33.3 & - & - & 30 & 23.8 \\
Others causes & 24 & 26.7 & 6 & 16.7 & 30 & 23.8 \\
\hline Total & $\mathbf{9 0}$ & $\mathbf{1 0 0 . 0}$ & $\mathbf{3 6}$ & $\mathbf{1 0 0 . 0}$ & $\mathbf{1 2 6}$ & $\mathbf{1 0 0 . 0}$
\end{tabular}

Source: Field Survey

Among 21 respondents who were not interested to study in future, 52.4 percent said it was over age which makes them shyness for joining school again with younger ones $83.3 \%$ among females and $40 \%$ percent among males. Similarly $23.8 \%$ child laborers reported that after a long gap they don't want to study again and 23.8 percent reported different causes such as family's responsibility, some are busy in other technical training, interest in earning money and Some child laborers told that there is not fixed job opportunity in the future even if they study further in the future.

\section{Findings}

The literacy rate of parents of child laborers is low because of poverty and awareness. The large families can't afford sufficient food and other basic needs. Hence, children are compelled to leave their place of origin for their survival or family economy support. Presents of step mother or death of both parents creates domestic violence in family, which is one of the reasons for driving children out of their home. Household poverty and starvation drive the children to search for job. So, it can be concluded that household poverty and starvation drive the children to search for job. In Makawanpur district high numbers of people are from Tamang community, but they have poor socio economic condition, which impact appear on child. Child laborers reported that they took money from their masters for their personal expenditure.

Poverty, unemployment, hard life in origin, limited economic opportunities, natural calamities, political insurgency and insecurity, which are push factors. Better economic opportunities, security, improved livelihood, etc. are pull factors to migrate from rural to urban areas. In my observation I found that most of the child respondents have mobile phone, and they replied that they had listened radio/F.M on their mobile. Out of total respondents, more than one half (52\%) joined hotel, teashop and restaurant to help for family income followed by those who worked to support for their study (20\%), get relief from their study (20\%) and $8 \%$ others (i.e. hard life if village, wanted to enjoying in city, bad relation to their parents). As a whole all the child were are not satisfied with their job. 


\section{Conclusions}

The survey findings, as enumerated above have revealed a number of critical areas for serious concern in any approach for elimination of the exploitative phenomenon of child labour in Nepal. By comparing the previous condition of child labour, little improvements have been appeared but there is not very satisfaction. Children are still working in miserable conditions. The study shows that hotel work is one of the most visible, hazardous and exploitative forms of child labour. Overall discussions lead to conclusion that poverty and illiteracy are the dominant reasons for child labour in the study area. All of these working children have been living miserable condition, suffering unhygienic working environments and long hours at low pay and there is virtually no sector in which children are not employed compromising their educational and socialization rights. The extreme household poverty is the leading cause of child labour in general. However, other factors large family size, illiteracy, unequal access to resource, lack of schooling facilities, etc. also contribute children to enter into labour market at this early age. In our findings most of the child laborers are from Tamang and Chepang community. Still now these communities are at the bottom of the society. They don't have enough education, good health and social circulation. At last it is concluded from the study that child laborers in hotel is one of the visible, exploitative and hazardous forms of child labour and poverty is both the cause and consequence of child labour. It is linked to the socio-economic, political and cultural realities of the country. The adoption of new laws and policies only can't prevent the child labour problem unless society as a whole is mobilized in this direction. Hence, social mobilization is an important device for building awareness and bringing about positive change to prevent and protect working children in society.

\section{References}

Action Aid, (1995). Listening to Smaller Voices. Children in an Environment of Change. London: Action Aid.

Bal Kumar, K.C., Suwal, B.R., \& Adhikari, K.P. (1997). Child Labour Situation in Nepal, Report from Migration and Employment Survey, 1995/96/98. Kathmandu: CDPS/ILO.

Bal Kumar, K.C., \& Dhanendra, V.S. (1999). The Nature and Magnitude of Working Children in Nepal. Nepal Population Journal, Vol.8 (7),PP. 1-32.

Bal Kumar, K.C., Swal,B.R., Adhikari, K.P., \& Gurung, Y.B. (1997). Migration of Working Children in Nepal.Kathmandu: CDPS.

Bequele, A., \& Boyden, J. (1998). Combating Child Labour. Geneva: ILO.

Bequele, A., \& Mayers, W. E.(1995). First Things First in Labour. Eliminating Work Detrimental to Children. Geneva: ILO/UNICEF.

CBS, (1997). Nepal Living Standard. CBS Survey Report- 1996, 1988 and 1999, Vol. I and II. CWIN, (2002). The State of the Rights of the Child in Nepal. National Report-1998, 2001 and 2002. Kathmandu: CWIN.

CWIN, (2002). Child Labour in Bidi Industries in Nepal. National Report-1998,2001 and 2002. Kathmandu: CWIN.

CWIN, (1995). Voice of Child Works. National Report-1992 and 1995. Kathmandu: CWIN. CWIN, (1989). Urban Child Labour in Nepal. National Report. Kathmandu: CWIN.

CWIN, (1987). Hotel Kanchha in Kathmandu: A Survey Report of Kathmandu. National 
Report, PP. 11-17.

CONCERN, (2003). Child Labour in Restaurants and Teachers in Nepal. A National Survey. Kathmandu: CONCERN-Nepal.

CWCCD, (1997). Situation of Analysis of Child Labour in Nepal. Kathmandu: Centre for Women/Children and community Development.

Dahal, B.N. (1989). Major Causes to be Child Workers in Nepalese HillyVillage. Voice of Child Worker's, No. 6, PP. 26-30.

Ennew, J. (1995). Learning of Laboring: A Complication of Key Texts on Children's Work and Basic Education. London: UNICEF.

ILO/IPEC, (1995). A Child Labour in Nepal. Kathmandu: ILO.

ILO/IPEC, (1996). Designing A National Framework of Action Against Child Labour in Nepal.

Kathmandu: ILO.

ILO/IPEC, (1994). Action for the Elimination of Child Labour Overview of the Problems and Responses. Geneva: ILO.

ILO/IPEC, (1973). ILO Minimum Age Convention. Geneva: ILO.

INSEC, (1996). Survey Report on Prevention of Migration of Children for the Purpose of Employment, Nepal. Kathmandu: INSEC.

Khaniya, T.R.(1995).Basic Primary and Vocational Education in Nepal. Kathmandu: IPEC/ ILO.

Marcus, R., \& Caroline, H. (1996). Small Hands: Children in the Working World. Working Paper, 16, London: Save the Children.

MOPE/HMG, (2000). Nepal Population Report. Kathmandu: MOPE.

Patterson, S.H. (1943). Social Aspects of Industry. New York: UNDP.

Pradhan, G. (1995). An Overview of the Child Labour in Nepal. Kathmandu: ILO.

Sattaur, O. (1993). Child Labour in Nepal. A Report by Anti-Slavery International and CWIN. Kathmandu: CWIN/Anti-Slavery International.

United Nation (UN), (1989). The UN Convention on the Right of the Child.New York: Oxford University Press.

United Nations Children's Fund (UNICEF), (1997). State of the world's Children Report. New York: UNICEF. 